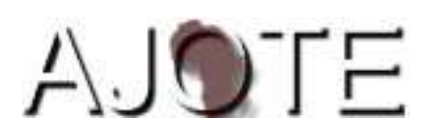

African Journal of Teacher Education

ISSN 1916-7822. A Journal of Spread Corporation

Volume $82019 \quad$ Pages 218-237

\title{
Effect of Student Teams Achievement Division and Think-Pair-Share on Students' Achievement in Reading Comprehension
}

\author{
Eucharia Okwudilichukwu Ugwu \\ Department of Arts and Social Sciences Education, \\ University of Ibadan, Nigeria \\ E-mail: okwudili555@gmail.com
}

\begin{abstract}
The study investigated the effect of two cooperative learning strategies, Student Teams-Achievement Divisions (STAD) and Think-Pair-Share (TPS) on senior secondary school students' achievement in reading comprehension in Vandeikya Local Government Area, Benue State, Nigeria. A total of 78 students (43 males and 35 females), drawn from three secondary schools participated in the study. Experimental and control conditions were randomly assigned to the three intact classes: EG1 (STAD), EG2 (TPS) and CG (Control Group). The instrument used were Reading Comprehension Achievement Test ( $r=0.784)$ and Lesson Plans (Teachers' Instruction Guides). Data were analyzed using Mean, Standard Deviation and Analysis of Covariance (ANCOVA). The results show higher achievement gains for students in the EG1 and EG2 over those of the CG, but not across gender. The findings support the existing evidence on the efficacy of cooperative learning over the traditional teaching method. English language teachers will therefore find the two techniques useful in teaching reading comprehension.
\end{abstract}

Keywords: cooperative learning, Student Teams-Achievement Divisions, Think-Pair-Share, academic achievement, reading comprehension

\section{INTRODUCTION}

Nigeria is one of the countries with a high rate of illiteracy. The Human Development Report shows that within 15years (2005 - 2015), the literacy rate of Nigerian adults (15 years and older) stood at 59.6 
(that means, an illiteracy rate of 40.1\%). Nigeria's literacy rate is far below that of Cameroun (75\%), Ghana (76.6\%), Togo (66.5\%) and Equatorial Guinea (95.3). Those of the youths between 25-24year stood at 65.3(females - F) and 79.9 (males - M). These are still far below the abovementioned African countries: Ghana (89.9\% - F, 91.3\% - M); Cameroun (80.4\% - F, 87.1\% -M), and Togo (81.4\% - F, $88.9 \%$-M) and Equatorial Guinea (98.8\% - F, 97.7\% - M) respectively (United Nations Development Programme 2016, 232). In the present situation, helping students to read is a key to increasing the literacy rate. Reading is so central to education that students who are not able to read encounter problem in their overall achievement, including in other subjects.

However, the teaching of reading is sometimes taken for granted in Nigeria. In most public schools (both primary and secondary), the teaching of reading is left solely in the hands of English language teachers, many of whom are only trained to teach English. Since these teachers are not professionally prepared to teach reading, they end up either avoiding it or just teaching it anyhow. Besides, there seems to be a general assumption that students learn to read by mere going to school; that is to say, they learn to read by reading - through trial and error, even without receiving specific instructions on how to read. The fact that instructions are delivered in English which is a second language in Nigeria and the textbooks are also written in English compound students' problems of learning to read due to their low proficiency in the language.

Reading as the pivot of literacy (Onukaogu \& Moh, 2008) needs special skills and if students are not helped to develop those skills, they may continue to struggle with reading all through their school years. Students who can read will most likely perform better in school than those who cannot read. Muodumogu and Ajegena (2011) explain that for excellence to be achieved in academics, learners need to be good readers who can read and comprehend texts in their various disciplines. The better reader a learner is, the more learning he/she acquires. It is nearly impossible for learners who cannot read to participate fully in the teaching-learning process, copy notes, do class and home works, extract meaning from the textbooks, write examinations and be meaningfully assessed.

Given the roles of reading in education, finding ways to facilitate its teaching is therefore necessary. Existing research evidence indicates the effectiveness of cooperative learning over the traditional teaching method in different school subjects. This study therefore investigated the possible effect of two cooperative learning strategies (Student Teams-Achievement Division and Think-Pair- 
Share strategies) on students' achievement in reading comprehension in selected Nigerian secondary schools.

\section{THEORETICAL UNDERPINNING}

The theory underpinning this study is the Social Development Theory propounded by Lev Vygotsky, a Russian social cognitivist in 1978. Vygotsky explains that social interaction (speech and practical activity) precedes intellectual development and that cognitive skills and consciousness originate from social relation and culture. Social, interpersonal and linguistic factors therefore, facilitate children's mental development. The theory further argues that the potential for cognitive development depends upon the Zone of Proximal Development (ZPD). The Zone of Proximal Development describes the distance between the actual development level of a child (as determined by independent problemsolving) and the level of his/her potential development (determined through problem-solving under adult guidance) or in collaboration with more capable peers. This implies that children learn cognitive tasks through their interactions with older peers or adults. Children can equally perform certain tasks under adult guidance or with peer collaboration which they cannot do if they work independently. The adult or peer who guides a child to improve in knowledge is called the More Knowledgeable Other (MKO).

Social development theory is closely related to the concept of cooperative learning in the sense that CL is rooted in social interaction. Sharing and discussion in the classroom gives learners opportunities to learn from one another. Learners are able to bring in their diverse experiences and skills into the reading classroom. In both STAD and Think-Pair-Strategies, learners with different academic abilities are paired so that they can learn from one another and achieve the group goals. As learners engage in discussion, they become MKO to one another since each person has something to contribute in the learning process. Similarly, the teacher as a more experienced person facilitates and directs the students in their learning process, thus serving as an MKO to all of them.

\section{Literature Review}

The centrality of reading to formal education is unquestionable. If students are to succeed in school, they must be efficient at reading since almost all the academic activities exist in or eventually are documented in writing. Reading usually goes beyond recognizing words on a printed page. The end product of reading is comprehension; therefore, reading and comprehension are just two sides of the same coin. Without comprehension, reading becomes a futile and boredom activity. Reading enables AJOTE Vol. 8.1 (2019), 218-237 
students to acquire the information needed not only to excel in school or pass their examinations but to achieve the overall goals of schooling.

The importance of reading is even more pronounced in the present $21^{\text {st }}$ century. Reading comprehension is in fact, one of the basic skills students are expected to acquire in order to fit into the labor force and therefore, make meaningful contributions to the society at large. The ability to read opens the door to the acquisition of the required $21^{\text {st }}$ century applied skills such as critical thinking, problem solving, oral and written communications, information technology application, creativity and lifelong learning (Workforce Readiness Project, 2006). Moreover, all the interdisciplinary themes which schools are expected to promote in the $21^{\text {st }}$ century, including global awareness, financial, and entrepreneurial literacy, civic, health and environmental literacy are only open to students who can read. An efficient reader is one who is able to extract information in a text and use same to solve existential problems. This is made possible through comprehension - the ability to understand what is read.

Comprehension makes reading meaningful, interesting and worthwhile. Students are expected to read at a critical level by going beyond what is stated explicitly. However, reading comprehension can be a complex process and an uncritical reader can easily make a faulty conclusion. Brummitt-Yale (2008) explains that because reading comprehension is incredibly complex and multifaceted, readers do not develop the ability to comprehend texts quickly and independently. In other words, reading needs to be taught.

Rahvard (2010) maintains that reading comprehension may be especially difficult for students whose primary language is not English. This is because students are often confronted with readings from different content areas which may require them to apply specific strategies to enable them read efficiently. Thus, teaching reading comprehension is an important task that every language teacher needs to pay serious attention to. Adequate knowledge of vocabulary is a prerequisite for text comprehension. Thus, the reader must have a considerable amount of vocabulary bank in order to read meaningfully.

Some text comprehension strategies including generating initial questions before reading, responding to those questions along the line, summarizing the passage and discussing the text with others could facilitate comprehension. Moreover, for reading to be successful, it must be located within 
the four language skills (including listening, speaking and writing). These skills are interwoven and should be taught as such. Thus, making reading as interactive as possible becomes a necessity.

Although reading specialists are hardly present in the Nigerian secondary schools, the English language teachers who teach reading are hardly well-prepared for this very important task. Most of them rely on the traditional teaching method in which students are asked to read the comprehension passage in their English language textbooks and answer the questions that usually follow it. Sometimes, when students are not able to read, the teacher may simply read while the students listen. At the end, they are asked to answer some questions either orally or in writing. Many Nigerian classrooms are also arranged to portray 'the talking teacher and the listening learners'. Interactions among students during lessons are most times hardly encouraged. This method of teaching reduces students' ability to learn from one another or even believing that they can make meaningful contributions to the learning process. It can also lead to boredom. However, reading lessons require a teaching strategy which will make learners as active as possible.

Cooperative learning has been considered by many as an effective teaching method and an alternative to the traditional type. Cooperative learning (CL) refers to a teaching strategy in which small teams, each with students of different levels of ability use a variety of learning activities to improve their understanding of a subject (Rahvard, 2010). It is considered a practical, dynamic and an effective method of teaching. Cooperative learning has five essential elements: positive interdependence, face to face interaction, individual accountability, collaborative skills and group processing (Johnson, Johnson \& Holubec, 1994). According to Slavin and Cooper (1999), the intent of cooperative learning groups is to enhance the academic achievement of students by providing them with increased opportunity for discussion, learning from each other and for encouraging each other to excel. In a reading comprehension classroom, utilizing cooperative learning could be a way of harmonizing the four language skills (listening, speaking, reading and writing). It could also lead to active participation, deeper insights and greater understanding of texts as students offer and receive feedbacks to and from one another.

Dotson (2001) reports that out of the 67 studies on the achievement effects of cooperative learning, $61 \%$ found significantly greater achievement in it than in the traditional teaching method. Positive effects of cooperative learning is also said to exist in all grade levels, across gender and among students of low, medium and high academic achievements (Slavin, 2010). According to Johnson 
(2003), a meta-analysis of all studies on cooperative learning shows that the average person engaged in cooperative behavior performed at about two thirds of one standard deviation above the average person in a competitive and individualistic classroom.

There are many CL strategies, among which are Student Teams-Achievement Divisions (STAD) and Think-Pair-Share (TPS), two strategies used in the present study. The choice of STAD and Think-Pair-Share is based on the fact that they are simple to use. There are also existing evidence that the two techniques are helpful teaching techniques that could facilitate classroom participation and improve achievement as reported in Zarei (2012), Sampsel (2013), Karaçöp (2016), Khaleel and Hamdan (2017), Umam, Asiah, Wibowo and Rohim (2017) and Maulida (2017).

Student Teams-Achievement Divisions emphasizes the use of team goals and team success that can only be achieved if all members of the team learn the objectives being taught. Utami (2010) considers the team as the most important feature of STAD. At every point, emphasis is placed on team members doing their best for the team, and on the team doing its best to help its members. There are five components of STAD: Class presentation, Team study, Quizzes or Tests, Individual improvement scores and Team Recognition (Slavin 1991).

Think-Pair-Share (TPS) is another cooperative learning strategy designed to enable students formulate individual ideas about a topic and then share those ideas with their peers. In a Think-PairShare classroom, students are allotted time to reflect on a question so as to have a deeper understanding of a concept before sharing their thoughts with others. The group discussion that follows students' thinking offers them the opportunity for increased understanding, deeper insight and active participation in the teaching-learning process. Sharing with peers also leads to automatic correction and clarity (Robertson, 2006).

Gender, as a social category is related to literacy and academic achievement. This relationship has been the focus of some studies including Arellano (2013), Olaitan (2017) and Khaleel and Hamdan (2017). The results of studies focusing on gender as it relates to achievement are sometimes contradictory. Since Think-Pair-Share and STAD emphasize the need for mixed grouping of students (heterogeneous teams), gender was therefore considered as an important variable in this study. 


\section{Null Hypotheses}

Four hypotheses were tested at 0.05 levels of significance:

i. Student Teams-Achievement Division CL strategy has no significant effect on students' achievement in reading comprehension.

ii. $\quad$ Think-Pair-Share CL strategy has no significant effect on students' achievement in reading comprehension.

iii. There is no significant difference in the mean achievement scores in reading comprehension of male and female students exposed to Student Teams-Achievement Division cooperative learning strategy.

iv. There is no significant difference in the mean achievement scores in reading comprehension of male and female students exposed to Think-Pair-Share cooperative learning strategy.

\section{METHODOLOGY}

The study employed a non-randomized control group, pretest-posttest quasi-experimental design. Intact classes were used in order not to disrupt the normal classroom schedules. Experimental and control conditions were randomly assigned to three classes: two experimental groups (one for STAD and one for Think-Pair-Share) and one control group. Three co-educational public senior secondary schools in Vandeikya Local Government Areas of Benue State were purposively selected based on willingness to participate, the English language textbook used by the school, and the number of male and female students in the intended classes. From each school, one SS2 class was selected. A total of 78 students, 43 males and 35 females formed the sample size.

The instruments used for gathering the data were Reading Comprehension Achievement Test (RCAT) and Lesson Plans. The RCAT has Sections ' $A$ ' (demographics) and ' $B$ ' which contains two reading comprehension passages adapted from the New Oxford Secondary English Course for Senior Secondary Schools Book 2 (Banjo, Onaga, Elugbe, \& Akano 2004). The titles of the reading comprehension passages were removed and some words were changed. Each reading passage was followed by 15 questions ( 29 multiple choice and one fill-in the gap), making a total of 30 questions. The questions were generated by the researcher.

The researcher also developed 12 Lessons Plans (LP) (4 for each group). Four LPs reflected the 5 components of STAD and were used for the EG1, four reflected the 3 components of Think-Pair- 
Share for the EG2, and four reflected the traditional teaching method for the Control Group (CG). Each LP covered a 45-minutes lesson and includes a reading comprehension passage (the same text for all the groups). The reading passages were equally adapted from the New Oxford Secondary English Course for Senior Secondary Schools Book 2. Some passages were shortened to match the 45 minutes allotted for the lessons. Each comprehension passage was followed by questions for group works, individual tests and assignments. Each LP was accompanied by an Instructional Aid (charts) which were related to the ideas in the passages, and a Marking Guide.

The RCAT was validated by three lecturers in the Faculty of Education who made corrections and remarks on them. It was then trial-tested on 52 SS2 students (27 males and 25 females) in one school. A reliability of 0.784 was obtained after subjecting the data to appropriate statistical analysis. Students in the selected schools were given a pre-test (RCAT) on the same day. After that, three English Language teachers (one from each school) were trained as research assistants. They were taught the basics of cooperative learning, STAD and Think-Pair-Share. Students in the EG1 and EG2 were equally given a short orientation to familiarize them with the tenets of STAD and TPS strategies. Students in the EG1 (STAD) were grouped into 5-member learning teams using their scores in the pretest as a guide. Each team had at least two male and two female students. The EG2 (Think-Pair-Share) were divided into 3-member learning teams. Each team had at least one male and one female student. A weekly pairing timetable was prepared for this group using their pre-test scores. Team members were alternated each week as reflected on the time table.

The experimental and control groups were subjected to varied treatments thus: the EG1 was taught reading comprehension using the STAD strategy. The teacher presented each lesson following the 5 components of STAD (teach, team study, test, team score and team recognition). At the end of each lesson, students with the highest average scores were recognized as Greatest, Greater, and Great Teams respectively and were given gifts like exercise books, biros or pencils. The EG2 was taught reading comprehension using the Think-Pair-Share strategy. After the group activities, teacher read the questions one after the other and randomly called on few students from different teams to share their answers with the whole class. Students who gave the right answers were applauded. The Control Group was taught reading comprehension using the traditional teaching strategy. Students also answered the reading comprehension questions which were scored, and the scripts returned to them during the next class. 
All the lessons for the three groups took place in the students' classrooms within 45 minutes.

Each group received a total of four lessons (a lesson per week). After the four weeks teaching, an interval of two weeks was given, and students were given a post-test using the RCAT. Analysis of Covariance (ANCOVA) was used to test the hypotheses at 0.05 levels of significance while mean and Standard deviation were used to answer the research questions. The decision rule is that the null hypotheses are not accepted if the p-value is less than 0.05 while it is accepted if the p-value is greater than 0.05 .

\section{RESULTS}

H1: Teams-Achievement Division (STAD) has no significant effect on students' achievement in reading comprehension.

Table 1: Mean and standard deviation of students exposed to STAD and those taught using the traditional teaching strategy

\begin{tabular}{|c|c|c|c|c|c|c|}
\hline \multirow[t]{2}{*}{ Group } & \multirow[t]{2}{*}{$\mathrm{N}$} & \multicolumn{2}{|c|}{ Pre -Test } & \multicolumn{2}{|c|}{ Post-Test } & \multirow[t]{2}{*}{ Mean gain } \\
\hline & & $\bar{x}$ & & $\bar{x}$ & $\delta$ & \\
\hline EG1 (STAD) & 24 & 6.79 & 2.17 & 13.94 & 2.94 & 7.15 \\
\hline Control group & 30 & 6.80 & 2.61 & 9.57 & 2.50 & 2.77 \\
\hline Mean difference & & & & 4.37 & & \\
\hline
\end{tabular}

Table 2: ANCOVA of students exposed to STAD and those taught using the traditional teaching strategy:

\begin{tabular}{lrrrrr}
\hline \multicolumn{1}{c}{ Type III Sum of Squares } & \multicolumn{3}{c}{ Mean Square } \\
\multicolumn{1}{c}{ Source } & Df & \multicolumn{1}{c}{ F } & Sig. \\
\hline Corrected Model & $279.323^{\mathrm{a}}$ & 2 & 139.662 & 19.887 & .000 \\
Intercept & 579.003 & 1 & 579.003 & 82.447 & .000 \\
Pre-STAD Test & 22.167 & 1 & 22.167 & 3.156 & .082 \\
Group/Method & 257.419 & 1 & 257.419 & 36.655 & .000 \\
Error & 358.158 & 51 & 7.023 & & \\
Total & 7802.000 & 54 & & & \\
\hline
\end{tabular}

a. $\mathrm{R}$ Squared $=.438($ Adjusted $\mathrm{R}$ Squared $=.416)$ 
As shown in Table 1, the mean achievement scores of students in the EG1at pre-test was 6.79 with a standard deviation of 2.17 while that of the control group (CG) was 6.80 with a standard deviation (SD) of 2.61. After the post-test, the mean achievement scores of the EG1 increased to 13.94 (SD 2.94) and $9.57(\mathrm{SD}=2.50)$ for the CG. The mean gains of the EG was 7.15 while that of the CG was 2.77. This means that the EG1 had a higher mean gain after post-test, implying that STAD led to higher achievement in reading comprehension for the former than the latter. Further statistical analysis as shown in Table 2 indicates that $F_{(1,51)}=36.655$ and $p=.000$. Since $p(0.000)$ is less than 0.05 , that is, $\mathrm{p}(0.000)<0.05)$, the null hypothesis was not accepted. This implies that there is a significant difference in the mean achievement scores of students exposed to STAD and those exposed to the traditional teaching strategy in the RCAT.

H2: Think-Pair-Share has no significant effect on students' achievement in reading comprehension.

Table 3: Mean and standard deviations of achievement of students exposed to Think-Pair-Share and those taught using the traditional teaching strategy

\begin{tabular}{lrrrrrr}
\hline Group & N & Pre -Test & \multicolumn{2}{c}{ Post-Test } & \multicolumn{2}{c}{ Mean gain } \\
\hline & & $\bar{x}$ & $\delta$ & $\bar{x}$ & $\delta$ & \\
EG2 (Think-Pair-Share) & 24 & 9.04 & 2.20 & 14.79 & 3.32 & 5.75 \\
Control & 30 & 8.13 & 2.84 & 11.47 & 2.83 & 3.34 \\
Mean difference & & & \multicolumn{2}{c}{3.32} \\
\hline
\end{tabular}


Table 4: ANCOVA of students' achievement in reading comprehension using Think-Pair-Share and traditional teaching strategies respectively

\begin{tabular}{|c|c|c|c|c|c|}
\hline & Type III Sum of Squares & & Mean Square & & \\
\hline Source & & Df & & $\mathrm{F}$ & Sig. \\
\hline Corrected Model & $3.445^{\mathrm{a}}$ & 2 & 1.723 & 40.219 & .000 \\
\hline Intercept & 2.783 & 1 & 2.783 & 64.979 & .000 \\
\hline Pre-TPS Test & .012 & 1 & .012 & .285 & .596 \\
\hline Group & .479 & 1 & .479 & 11.182 & .002 \\
\hline Error & 2.184 & 51 & .043 & & \\
\hline Total & 358.389 & 54 & & & \\
\hline Corrected Total & 5.629 & 53 & & & \\
\hline
\end{tabular}

a. R Squared $=.612($ Adjusted R Squared $=.597)$

The result in Table 3 shows the mean achievement scores in reading comprehension of the EG2 and the CG after the pre-test is 9.04 and 8.13 with standard deviations of 2.20 and 2.84 respectively. After the post test, both the means and standard deviations changed to 14.79 ( $\mathrm{SD}=3.32$ ) for the EG2 and $11.47(\mathrm{SD}=2.83)$ for the $\mathrm{CG}$. The mean gain for the experimental and control groups were 5.75 and 3.34 respectively, with a mean difference of 3.32 in favor of the Think-Pair-Share group. The test of hypothesis as shown in Table 4 reveals that $F_{(1,51)}=11.182$ and $p=0.002$. Since the $\left.p(0.002)\right)<.05$, the null hypothesis that Think-Pair-Share has no significant effect on students' achievement in reading comprehension is not accepted. The implication is therefore, that Think-Pair-Share has a significant effect on students' achievement in reading comprehension.

H3: There is no significant difference in the mean achievement scores in reading comprehension of male and female students exposed to STAD.

Table 5: Mean and standard deviation of male and female students who were exposed to STAD

\begin{tabular}{|c|c|c|c|c|c|c|}
\hline \multirow[t]{2}{*}{ EG1 (STAD) } & \multirow[t]{2}{*}{$\mathrm{N}$} & \multicolumn{2}{|c|}{ Pre-test } & \multicolumn{2}{|c|}{ Post-test } & \multirow[t]{2}{*}{ Mean gain } \\
\hline & & $\bar{x}$ & $\delta$ & $\bar{x}$ & $\delta$ & \\
\hline Male students & 14 & 7.07 & 6.56 & 14.29 & 2.70 & 7.22 \\
\hline Female students & 10 & 6.40 & 6.46 & 13.50 & 3.34 & 7.10 \\
\hline Mean difference & & & & 0.79 & & \\
\hline
\end{tabular}


Table 6: ANCOVA of the mean achievement scores in reading comprehension of male and female students exposed to STAD

\begin{tabular}{lrrrrr}
\hline & Type III Sum of Squares & \multicolumn{3}{c}{ Mean Square } & \\
Source & & Df & & F & Sig. \\
\hline Corrected Model & $4.322^{\mathrm{a}}$ & 2 & 2.161 & .233 & .794 \\
Intercept & 375.500 & 1 & 375.500 & 40.514 & .000 \\
Pre-STAD Test & .721 & 1 & .721 & .078 & .783 \\
Sex & 3.034 & 1 & 3.034 & .327 & .573 \\
Error & 194.636 & 21 & 9.268 & & \\
Total & 4875.000 & 24 & & & \\
Corrected Total & 198.958 & 23 & & & \\
\hline
\end{tabular}

a. $\mathrm{R}$ Squared $=.022($ Adjusted R Squared $=-.071)$

Table 5 indicates that the mean achievement scores of male students in reading comprehension before the intervention program was 7.07 with a standard deviation of 6.56. That of the female students prior to treatment was 6.40 with a standard deviation of 6.46. After the treatment, the mean achievement scores in reading comprehension of male and female students were 14.29 and 13.50 with standard deviations of 2.70 and 3.34 respectively. The mean gain of the male students was 7.22 while that of female students was 7.10, (indicating a slight difference of 0.79, in favor of the male students). However, as shown in Table 6, the $\mathrm{F}_{(1,21)}=.327 \mathrm{p}=.573$. Since the $\left.\mathrm{p}(.573)>.05\right)$, the null hypothesis is accepted. This means that gender has no significant effect on the achievement in reading comprehension of students exposed to STAD.

H4: There is no significant difference in the mean achievement scores in reading comprehension of male and female students exposed to Think-Pair-Share. 
Table 7: Mean and standard deviation of achievement in reading comprehension of male and female students exposed to Think-Pair-Share cooperative learning strategy

\begin{tabular}{lrrrrrrr}
\hline $\begin{array}{l}\text { EG2 } \\
\text { (Think-Pair-Share) }\end{array}$ & N & \multicolumn{3}{c}{ Pre-Test } & & Post-Test & \multicolumn{2}{c}{ Mean gain } \\
& & & & & & & \\
& & $\bar{x}$ & $\delta$ & & $\bar{x}$ & \multicolumn{1}{l}{$\delta$} & \\
Male students & 9 & 9.29 & 2.20 & 14.71 & 3.00 & 5.42 \\
Female students & 11 & 8.70 & 2.26 & 14.90 & 3.90 & 6.20 \\
Mean difference & & & & & 0.19 & & \\
\hline
\end{tabular}

Table 8: ANCOVA of achievement scores in reading comprehension of male and female students exposed to Think-Pair-Share cooperative learning strategy

\begin{tabular}{lrrrrr}
\hline \multicolumn{1}{c}{ Type III Sum of Squares } & \multicolumn{3}{c}{ Mean Square } & \multicolumn{2}{c}{ Sig. } \\
\hline Corrected Model & Df & \multicolumn{1}{c}{ F } & \\
Intercept & $.416^{\mathrm{a}}$ & 2 & .208 & .017 & .983 \\
Pre-TPS Test & 264.396 & 1 & 264.396 & 21.899 & .000 \\
Sex & .215 & 1 & .215 & .018 & .895 \\
Error & .257 & 1 & .257 & .021 & .885 \\
Total & 253.542 & 21 & 12.073 & & \\
Corrected Total & 5505.000 & 24 & & & \\
\hline
\end{tabular}

a. $\mathrm{R}$ Squared $=.002($ Adjusted $\mathrm{R}$ Squared $=-.093)$

Table 7 shows that the mean achievement scores of male students exposed to Think-Pair-Share at pretest was 9.29 with a standard deviation of 2.20 while that of female students was 8.70 with a standard deviation of 2.26. The mean achievement score of male students at post-test was 14.71 and a standard deviation of 3.00. On the contrary, female students had a mean achievement score of 14.90 and a standard deviation of 3.90 after treatment. The mean gain of the experimental and control groups were 5.42 and 6.20 respectively. The mean difference of the two groups was 0.78 in favor of female students.

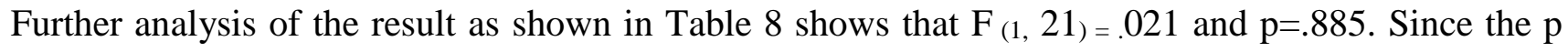
value (.885) is greater than the alpha level (0.05), that is, $\mathrm{p}(.885)>.05)$, the null hypothesis is accepted. AJOTE Vol. 8.1 (2019), 218-237 
This means that gender has no significant effect on the achievement in reading comprehension of students exposed to Think-Pair-Share comprehension.

\section{DISCUSSION}

The results show that STAD and Think-Pair-Share have significant effect on students' achievement in reading comprehension. Students in the EG1 and EG2 both scored higher marks than their counterparts in the CG after the trio were taught reading comprehension for four weeks. The findings are consistent with previous studies such as Robertson (2006), Zarei (2012), Sampsel (2013), Karaçöp (2016), Umam, Asiah, Wibowo and Rohim (2017) and Khaleel and Hamdan (2017). However, Ishtiaq, Ali and Salem (2017) reported no significant difference among the control and experimental groups when STAD was used among adult learners. Although STAD, and indeed any cooperative learning strategy cannot be said to guarantee automatic successful learning outcome, the study by Ishtiaq, Ali and Salem (2017) covered a short period. The treatment was administered for only two weeks which might not be sufficient to investigate the effect of a teaching strategy especially if the participants are not familiar with the technique. A longer period would have been better.

Moreover, Nath and Ross (1996) as cited in Dotson (2001) reported that if teachers did not strictly adhere to the framework of CL, the method is unsuccessful, and students spend more time on disagreement or conflict management than on academic tasks. Similarly, Maulida (2017) found out that teachers have different approaches to the Think-Pair-Share in teaching reading comprehension. The variation could contribute to the differing effects. Maulida also reported that the TPS technique is not without problems such as inadequate preparation and students' limited vocabulary. In other words, other intervening variables could contribute to the success or failure of cooperative learning teaching techniques.

The result is consistent with Slavin (2010) which asserts that cooperative learning is an alternative to the traditional teaching strategy. There is an indication that students in the Experimental Group 1 and 2 understood the reading comprehension passages better as reflected in their higher mean gains. One important aspect of Think-Pair-Share and STAD is that they enhance classroom interaction among students due to the compulsory group works. Constant interaction makes them to be more active than in the traditional teaching method in which every student is on his/her own and responsible to the teacher. Perhaps there was also the excitement of wanting to be the best group and possibly receiving a gift at the end. Sampsel (2013) had earlier discovered that students exposed to TPS technique 
increased their classroom participation, contribution to the learning process and confidence. One of the objectives of CL is to give students room to contribute meaningfully to the learning process. This is achieved in smaller groups than in the large classes. Reading comprehension requires this active participation.

The findings are also consistent with the views of Utami (2010) that STAD is one of the simplest CL strategies which can be effectively used by teachers who are new to cooperative learning. During the training of the research assistants, it was evident that they were all new to cooperative learning. In spite of that, they were able to utilize the strategies after barely a week's training. It is interesting to note that all the students - both in the CG and the EG actually improved in their mean achievement scores after being taught reading comprehension. Their improvements were irrespective of the strategies used. This shows that it is very important for teachers to teach reading comprehension meaningfully.

The result shows that gender has no significant effect on students' achievement in reading comprehension. Tables 5 and 7 reveal that both male and female students who were taught reading comprehension using the STAD and Think-Pair-Share strategies improved in their mean achievement scores. The two Tables also show that while male students who were exposed to reading comprehension using STAD scored higher that the female students (Table 5), female students who were exposed to Think-Pair-Share scored higher than the male students (Table 7). However, ANCOVA analysis of these two results (Tables 6 and 8) revealed that the differences are not statistically significant. This indicates that both STAD and Think-Pair-Share CL strategies are effective in improving students' achievement in reading comprehension irrespective of their gender.

This finding is in line with an earlier study of Amosun and Isokpehi (2009) who reported that male and female students taught with cooperative learning strategies performed better than those taught with the traditional teaching strategy. However, when the results of male and female students were compared, the effect did not differ across gender. A similarly result was obtained by Peklaj (2003) who equally reported that although boys who were exposed to the cooperative learning strategy scored higher than their female counterparts, the difference was not statistically significant. This has further confirmed the claim by Slavin (2010) that the positive effect of CL exists in all grade levels and across gender. 
An earlier study by Khaleel and Hamdan (2017) shows that Think-Pair-Share strategy led to higher achievement gains for students than the traditional teaching method and even higher gains for female than male students that participated in the study. Although the difference in achievement between boys and girls in the present study is not statistically significant, there is an indication that girls in Think-Pair-Share group outperformed the girls. It is not particularly clear why this happened and why the STAD favored boys more than the girls. Arellano (2013) had reported that female students obtain better global results than their male counterparts in reading comprehension in English as a foreign language. There are many variables other than teaching method that could affect students' achievement. Besides, effective as cooperative learning may be, the results may not be similar in all cases. There are a great many teaching strategies and what works for one group may not work for another.

Popoola (2011) emphasized the need for teachers to promote gender equality in the classroom so as to enhance students' achievement. Despite the limited scope of this study, findings seem to indicate that using Think-Pair-Share and STAD might be helpful in closing gender gaps as it relates to achievement in reading comprehension. The strategies tend to offer students equal opportunities to participate in the teaching-learning process and thus enhance their comprehension.

\section{IMPLICATION OF THE RESEARCH}

The results of this study have implications for students and teachers of English language. To students, it is evident that if they collaborate with one another in the learning process, they will more likely enhance their learning. Therefore, they need to be encouraged to see the gains of collaboration rather than competition in the classroom. Cooperative learning activities helped students to learn from one another, thereby making their reading comprehension more productive. If they apply these collaborative skills when learning other school subject, their learning may equally be enhanced.

However, students are hardly able to organise themselves into learning groups without the aid of teachers. Therefore, the result has implication for teachers. Teachers need to incorporate cooperative learning activities in their classrooms and monitor student activities so that they do not lose focus of the group goals. Using STAD and Think-Pair-Share could help teachers to be more creative in teaching reading thereby removing the boredom that is sometimes associated with reading comprehension lessons. Also, teachers who teach in overcrowded classrooms may find the two strategies as helpful alternative ways of handling such classes by grouping learners into manageable teams. 
The simplicity and ease with which the teachers mastered the STAD and Think-Pair-Share techniques have implications for the in-service training of English language teachers. The teachers who participated in the study had no prior experience of using the techniques in their classroom, yet, a week's informal training was sufficient for them to utilise them. Thus, school administrators and the government may consider organising in-service training of teachers to acquaint them with the different techniques of cooperative learning in order to maximise teaching and learning.

\section{CONCLUSION}

Although the sample population used in the study is small and the duration of the study was not long enough to warrant generalization, the result adds to the pool of existing literature on the effectiveness of cooperative learning, especially STAD and TPS in improving students learning. It is also evident that the two strategies are beneficial to all students irrespective of their gender. Teachers who find the teaching of reading comprehension a herculean task might benefit from the two strategies.

\section{References}

Amosun, P. A., and Isokpehi, O. L. (2009). Effects of graffiti cooperative learning Strategy (GCLS) and group investigation (GI) on social studies achievement in junior secondary schools in Ibadan. Ibadan Journal of Educational Studies, 6(1 \& 2), 1-12.

Arellano, M. D. C. (2013). Gender differences in reading comprehension achievement in English as a foreign language in Compulsory Secondary Education. Tejuelo, 17, 67-84.

Banjo, A., Onaga, U., Elugbe, B., and Akano, A. (2004). New Oxford Secondary English Course for Senior Secondary Schools 2. Ibadan: University Press Plc.

Bilesanmi-Awoderu J. B., and Oludipe, O. D. (2012). Effectiveness of cooperative learning strategies on Nigerian junior secondary students' academic achievement in basic science. British Journal of Education, Society \& Behavioral Science, 2(3), 307-325. Retrieved from

http://www.sciencedomain.org/abstract.php?iid=124\&id=21\&aid=664

Brummitt-Yale, J. (2008-2014). What is reading comprehension? Retrieved from http://www.k12reader.com/what-is-reading-comprehension/

Dotson, J. M. (2001, Winter). Cooperative learning structures can increase student 
Effect of Student Teams Achievement Division and Think-Pair-Share on Students' Achievement in Reading Comprehension

achievement. Kagan online magazine. Retrieved from http://www.kaganonline .com/free_articles/research_and_rationale/increase_achievement.phh

Ishtiaq, M., Ali, Z. and Salem, M. (2015). The Effects of Student Teams Achievement

Division (STAD) on Motivation of Saudi EFL Adult Learners. International Journal of Language Education and Applied Linguistics (IJLEAL), 3, 11-24. Retrieved from http://ijleal.ump.edu.my/

Johnson, D. W. (2003). Social interdependence: Interrelationships among theory, research, and practice. Retrieved from http://www.sfu.ca/ jcnesbit/EDUC220/ThinkPaper/Johnson2003.pdf

Johnson, D. W., Johnson R. T., Holubec E. J. (1991). Cooperation in the classroom. Retrieved from http://www.csudh.edu/dearhabermas/cooplrn.htm

Karaçöp, A. (2016). Effects of Student Teams-Achievement Divisions Cooperative

Learning with Models on Students' Understanding of Electrochemical Cells. International Education Studies, 9(11), 104-120. Retrieved from doi:10.5539/ies.v9n11p104

Khaleel, R. and Hamdan, A.( 2017). The Effect of (Think - Pair - Share) Strategy on the Achievement of Third Grade Student in Sciences in the Educational District of Irbid. Journal of Education and Practice, 8(9) 88-95. Retrieved from www.iiste.org.

Maulida F. (2017). The use of think-pair-share in teaching reading comprehension. A Case study of the English Teachers in SMKN 1 Randudongkal in the Academic Year of 2016/2017. Journal of English Language Teaching, 6(1), 49-58. Retrieved from http://journal.unnes.ac.id/sju/index.php/elt

Muodumogu, C. A., and Ajegena, D. J. O. (2011). Effects of strategy study skills development on students' achievement in the reading of economics text. Literacy and Reading in Nigeria, 13(1), 45-51.

Olaitan, A. J. (2017). Effects of Gender and School Location on the Ekiti State Secondary Schools Students' Achievement in Reading Comprehension in English Language. Journal of Education and Practice. 8(5). www.iiste.org

Onukaogu, E. O., and Moh, F. (2008). Let's appropriate the pearls in reading that we may live and not barely exist. In O. Emejulu, L. Uwatt and A. E. Arua (Eds.), Topical issues in literacy, language and development in Nigeria (pp. 258-281). Newark, DE: International Reading Association. 
Peklaj, C. (2003). Gender, abilities, cognitive style and students' achievement in cooperative learning. Horizons of Psychology, 12(4), 9-22. Retrieved from http://www.psy.ff.unilj.si/psiholoska_obzorja/arhiv_clanki/ 2003_4/peklaj.pdf

Popoola, A. A. (2011). Influence of literacy on gender parity in mathematics lessons. Literacy and Reading in Nigeria, 13(1), 9-19.

Rahvard, Z. J. (2010). Cooperative learning strategies and reading comprehension. California Linguistic Notes, 25(2), 1-15. Retrieved from http://english.-fullerton.edu/publications/cln/clnarchives/2010spring/rahvard-coop-ED.pdf

Robertson, K. (2006). Increase student interaction with "Think-Pair-Shares" and "Circle chats. Retrieved from http://www.colorincolora-do.org/article/13346/

Sampsel, A. (2013). Finding the Effects of Think-Pair-Share on Student Confidence and Participation. Honors Projects. 28. Retrieved from https://scholarworks.bgsu.edu/honorsprojects/28

Slavin, R. E. (1991). Synthesis of research on cooperative learning-ASCD. Retrieved from www.ascd.org/ascd/pdf/journals/ed_lead-/el_199102_slavin.pdf

Slavin, R. E. (2010). Co-operative learning: What makes group-work work? In The nature of learning: Using research to inspire practice. Retrieved from http://www.oecdilibrary.org/education/the-nature-of-learning/co-operative-learning-what-makes-group-workwork_9789264086487-9-en

Slavin, R. E., and Cooper, R. (1999). Improving intergroup relations: Lessons learned from cooperative learning programs. Retrieved from http://www.jan.ucc.nau.edu/_slm/AdjCI/Teaching/Cooperative.html.

United Nations Development Programme (2016), Human Development Report 2016. Human Development for Everyone. Retrieved from http://hdr.undp.org/sites/default/files/2016_human_development_report.pdf

Umam K., Asiah, S. N., Wibowo, I. T. And Rohim, S. (2017). The Effect of Think-PairShare Cooperative Learning Model Assisted With ICT on Mathematical Problem Solving Ability among Junior High School Students. Hayashi, Y., et al. (Eds.) (2017). Workshop Proceedings of the 25th International Conference on Computers in Education. New Zealand: Asia-Pacific Society for Computers in Education.94-98.

Utami, T. (2010). (STAD). Student Teams-Achievement Division technique in 
Teaching reading comprehension to the tenth year students of SMA NEGRI I WirosariGrobogan in the academic year 2010/2011. Retrieved from http://www.diditlinguist.blogspot.com/2013/07/stad-student-teams-achievementdivision.html.

Vygotsky, L. S. (1978). Mind in society: The development of higher psychological processes. Cambridge, MA: Harvard University Press. Retrieved April 9, 2014 from http://www.worldcat.org/title/mind-in-society-the-development-of-higher-psychologicalprocesses/oclc/3517053

Workforce Readiness Project. (2006). Are They Really Ready to Work? Employers'

Perspectives on the basic knowledge and applied skills of new entrants to the 21 st century U.S. workforce. Retrieved from http://www.p21.org/storage/documents/FINAL_REPORT_PDF09-29-06.pdf

Zarei, A. A. (2012). The effects of STAD and CIRC on L2 reading comprehension and vocabulary learning. Retrieved from http://www.academia.edu/2442186/The_Effects_of_STAD_and_CIRC_on_L2_Reading_ 